\title{
A National Oceanographic Program
}

\author{
Harrison Brown \\ AND \\ RIChaRd VeTter \\ Respectively Chairman and Executive Secretary, \\ Committee on Oceanography \\ National Academy of Sciences-National Research Council, \\ Washington, D. C.
}

In February of 1957 a group of oceanographers and representatives from various agencies of the Federal Government met at the request of Dr. Bronk, President of the National Academy of Sciences, to discuss the question of whether or not the Academy should make a study of the status of the marine sciences. Present were representatives from the Navy, the Bureau of Commercial Fisheries, the Atomic Energy Commission, small and large oceanographic institutions, and other groups concerned with the marine sciences. They soon discovered that they had in common the knowledge that their day-to-day, month-to-month problems in the development of various programs could not be solved without a considerable increase in the development of marine sciences in the United States.

In its rapidly expanding development of complex weapons systems, the Navy has outstripped the storehouse of fundamental information available concerning its operating environment. Our understanding of processes affecting the harvesting of food from the sea are inadequate in comparison with the extensive development of agriculture. The sudden appearance of radioactivity in man's environment has created many problems for which knowledge of the oceans is required. Thus it was natural that the three main sponsors of the suggestion that the Academy conduct a special study of the needs for a national program in oceanography were the Navy, the Bureau of Commercial Fisheries, and the Atomic Energy Commission*.

* The National Science Foundation later joined this group of sponsors of the Committee on Oceanography.
During the course of the discussions, it became apparent that our rapidly expanding technology was placing tremendous demands on the few scientists who had been devoting their lives to the search for basic information about the seas.

Convinced that the Academy should conduct an extensive study of the nation-wide needs for oceanography, Dr. Bronk appointed Dr. Harrison Brown, Professor of Geochemistry at the California Institute of Technology, as chairman of the new committee. Later, the full membership consisted of: Maurice Ewing, Lamont Geological Observatory, Columbia University; Columbus O'D. Iselin, Woods Hole Oceanographic Institution; Fritz Koezy, Marine Laboratory of the University of Miami; Sumner Pike, formerly Commissioner, U. S. Atomic Energy Commission; Colin Pittendrigh, Department of Biology, Princeton University; Roger Revelle, Scripps Institution of Oceanography; Gordon Riley, Bingham Oceanographic Laboratory, Yale University; Milner B. Schaefer, Inter-American Tropical Tuna Commission; and Athelstan Spilhaus, Institute of Technology, University of Minnesota.

\section{COMMITTEe RePorT}

The first meeting of this group, held in November, 1957, was followed by week-end meetings approximately every two months. The Committee met at several of the centers of oceanography in the United States in order to become more fully acquainted with the local problems as well as the national needs.

In February of 1959, a summary of the findings of the Committee was released to the Gov- 
ernment agencies sponsoring the study, to the Congress, and to the public. The essence of the Committee's recommendations are contained in a short section from Chapter I headed General Recommendations which follows.

"The key to the growth of oceanography in the United States lies in basic research-research which is done for its own sake without thought of specific practical applications. The very nature of basic research is such that the problem which will be attacked and the results which will be obtained cannot be predicted. The very nature of applied research is such that its success depends upon the size of the reservoir of fundamental knowledge upon which it must draw. The rate of progress in the applied marine sciences will be determined in the long run by the rate of progress in the basic marine sciences.

"The Committee has concluded that both the quantity and quality of basic research in the marine sciences can and should be increased substantially during the years ahead. Specifically the Committee recommends:

"The United States Government should expand its support of the marine sciences at a rate which will result in at least a doubling of basic research activity during the next ten years*.

"It should be emphasized that doubling the basic research activity will require more than doubling the total expenditures.

"A large part of the deliberations of the Committee were devoted to discussions of the conditions under which basic research can flourish. First and foremost, progress depends upon the interests, experience and creative imaginations of individual scientists. But the individual scientist does not work in a vacuum. He must have instruments and facilities. He must live in an atmosphere which is conducive to creative activity. These necessities in turn give rise to problems involving marine research laboratories-problems of leadership, financial stability, flexibility, growth, academic associations and physical facilities.

"Not only for research but in order to exploit and use the oceans we need more detailed knowledge which can be obtained only through

* In 1958 about 23 million dollars were spent for applied and basic oceanographic research. The basic research share of the total.was not over 9 million. About 8 million of this, including the 1958 share of IGY expenditures, were Federal funds. systematic surveys in three dimensions. These surveys should include such features as depth, salinity, temperature, current velocity, wave motion, magnetism, and biological activity. It is essential that these surveys be conducted on an ocean-wide ocean-deep basis as quickly as possible. Our knowledge is now limted largely to waters 100 miles from shore and even here it is inadequate for present and future needs. Accordingly, the Committee recommends:

"The increase in support of basic research should be accompanied during the next ten years by a new program of ocean-wide surveys. This will require a two-fold expansion of the present surveying effort.

"We believe that, on a long-range basis, basic research coupled with systematic ocean surveys are of paramount importance in solving a number of urgent practical problems involving military defense, the development of ocean resources and possible future increases of radioactive contamination of the seas resulting from the rapid development of atomic energy. However, research and surveys must go hand in hand with a vigorous and imaginative applied research and development program. Accordingly the Committee recommends:

"The United States should expand considerably its support of the applied marine sciences, particularly in the areas of military defense, marine resources, and marine radioactivity.

"The implementation of these general recommendations requires action upon a number of broad fronts. More marine scientists must be educated. Additional ships and shore facilities must be built. New instruments and techniques must be developed. International cooperation in the marine sciences must be strengthened.

"To achieve these aims in the next ten years will necessitate many agencies of the Federal Government working together both in planning and in providing the monies*. Taking into account the relative degrees of interest and importance of oceanography to individual agencies, the Committee recommends:

"The Navy and the National Science Founda-

* One method suggested for developing more effective inter-agency cooperation is through the proposed Federal Council for Science and Technology. This Council is described in Strengthening American Science, a recent report of the President's Science Advisory Committee. 
tion should each finance about 50\% of the new basic research activity except ship construction. The Navy should finance 50\% of the new research-ship construction with the Maritime Administration and the National Science Foundation sharing the remainder. The Navy, through the Hydrographic Office, should finance 50\% of the deep ocean surveys, while the Coast and Geodetic Survey should finance the balance. The Navy should sponsor completely all military research and development operations. The Bureau of Commercial Fisheries should finance the greater part of the recommended ocean resources program. The Atomic Energy Commission should finance the major part of the research dealing with the problems of radioactive contamination of the oceans. The National Science Foundation and the Office of Education should sponsor jointly the proposed program for increasing scientific and technical manpower in the marine sciences. Efforts aimed at fostering international cooperation in the marine sciences should be sponsored by the Department of State, the International Cooperation Administration and the National Science Foundation. Other agencies should take responsibility for certain aspects of the proposed program, particularly the Public Health Service, the Geological Survey and the Bureau of Mines.

"Although the bulk of oceanographic research and survey work must of necessity be financed by the Federal Government, the value of state and private funds cannot be overestimated. Such funds are especially helpful for supporting initial exploratory basic research and for starting new laboratories. Accordingly, the Committee recommends:

"Private foundations and universities, industry, and state governments should all take an active part in the recommended program of expansion."

The Committee's task in arriving at the above recommendations was not an easy one. As pointed out in its report, the broad field of scientific endeavor covered by the term "oceanography" introduced many complications. In its study, the Committee considered that oceanography could be defined as "the scientific study of all aspects of the oceans, their boundaries and their contents." Research is undertaken in a variety of private and Government laboratories; numerous Government agencies have direct but differing interests in the oceans. Indeed the breadth of the problems and subjects discussed was such that in the Committee's mind the terms "oceanography" and "marine sciences" are synonymous. Thus equal emphasis is placed upon the requirements of marine biology, physical oceanography, geology, chemistry, and the application of basic knowledge to special developmental problems.

In order to make recommendations under these circumstances, the following panels were formed for the purpose of making specific studies: Panel on Oceanographic Research Ships, Clifford A. Barnes, Admiral L. O. Colbert, John Isaacs, Columbus O'D. Iselin (Chairman), Vito Russo, and Herbert Seward; Panel on New Devices for Exploring the Ocean, Robert Frosch, James Lipp, Philip Mandel, Andreas Rechnitzer, Athelstan Spilhaus, Allyn Vine (Chairman), and Rear Admiral George Weaver; Panel on Ocean Resources, Richard L. Meier, H. W. Menard, John R. Menke, Milner B. Schaefer, Oscar E. Sette, Robert G. Snider (Chairman), Lionel A. Walford, and R. F. Nigrelli (Consultant); Panel on International Cooperation in the Marine Sciences, Columbus O'D. Iselin, Fritz Koczy, Roger Revelle, Milner B. Schaefer, and Athelstan Spilhaus (Chairman); Panel on Radioactivity in the Oceans, Howard Boroughs, Dayton Carritt, Walter Chipman, Harmon Craig, Lauren Donaldson, Richard Fleming, Richard Foster, Edward Goldberg, John Harley, Bostwick Ketchum, Louis Krumholz, Charles E. Renn, Roger Revelle (Chairman), Milner B. Schaefer, Allyn Vine, Lionel Walford, and Warren Wooster, with consultants: Theodore Folsom, Arnold Joseph, Robert Reid, and Donald Pritchard.

Although the total amount of money needed for the ten-year program outlined by the Committee appears large, the actual recommended rate of increase of basic research activity compared to the present level is somewhat less than $10 \%$ per year. The major expenditures required in the next few years are for the modernization and the long over-due replacement of old obsolete ships and facilities.

The essential limitation on the rate at which the marine sciences can expand effectively is that of available manpower. This point is stressed in the report by a series of specific recommendations on the need for additional financial 
support of faculty and graduate students in oceanography. The major problem of the Committee in formulating its recommended program was to balance the urgent need for rapid expansion against a reasonable rate of growth consistent both with the acquisition of welltrained and competent scientists and with an orderly expansion of existing laboratories and the development of new ones. Foremost in the minds of the Committee was the need to meet the current and future urgent needs for oceanographic knowledge and to avoid the necessity for a costly "crash" program at some future date. Indeed, the report stresses that the recommendations contained in it are considered to be minimal and that "action on a scale appreciably less than that recommended will jeopardize the position of oceanography in the United States relative to the position of the science in other major nations, thereby accentuating serious military and political dangers, and placing the nation at a disadvantage in the future use of the resources of the sea."

The first chapter of the Committee's report. released in February, 1959, contains the general recommendations listed above and a series of specific recommendations on Education and Manpower, New Ships, Shore Facilities for Basic Research, Ocean-wide Surveys, Engineering Needs, Radioactivity, Ocean Resources, International Cooperation, and Budget and Operations. More detailed discussions and information on each of the above subjects is being provided through a series of eleven supplemental chapters covering the subjects listed above plus Basic Research, Oceanographic Research for Defense Applications, a History of Oceanography in the United States, and a review of the Status of Marine Sciences in the United States as of 1958. Most of these chapters will have been finished and distributed by the time this article is published.

Although fairly detailed in some sections, particularly in describing the requirements for types of activities needed in ocean resources research, the report does not go into detail in describing fundamental basic research which can be carried out only under the inspired leadership of individual scientists. The report does not provide specific details on exactly how particular types of apparatus should be developed and constructed, but the general require- ments for new instrumentation are discussed. The report does not judge the relative merit of one institution as opposed to another or in any way attempt to pass judgment on specific scientific research projects, nor does it cover all specialities in the marine sciences, such as coastal geography, marine deterioration, etc. The goal throughout the report is to encourage as much freedom as possible in individual scientific pursuits and to construct the framework within which a vigorous, healthy, imaginative national program in the marine sciences can grow.

\section{Reaction to the Commitee Rigort}

The public interest and reaction to the report of the Committee on Oceanography far exceeded the expectations of the members of the Committee. Because of the very broad recommendations contained in the report, the Committee felt a quadruple responsibility to make its findings known to the Government sponsors of the Committee, to other branches of the Government, to the scientific community, and to the general public. The response in each of these areas has been and continues to be gratifying.

Government agencies-Almost simultaneous with the release of Chapter I of the Committee on Oceanography report, an internal Navy document, Project Tenoc, prepared by the Office of Naval Research, received strong endorsement from Admiral Arleigh E. Burke, Chief of Naval Operations. This project, independently derived by the Office of Naval Research, outlines the requirements for ship construction, laboratory construction, and the support of oceanographic research needed to meet the rapidly expanding needs of the Navy for oceanographic information over the period of the next ten years. The general similarity in terms of funds, numbers of ships and laboratories contained in the ProJEct Tenoc report with that portion of the same types of activities assigned to the Navy in the Committee on Oceanography's report tends to confirm the realistic appraisal of the needs and objectives achieved by both groups. The Navy has been and obviously will continue to be one of the strongest supporters of basic and applied oceanographic research in the United States. As one indication of the Navy's interest, the budget for fiscal year 1960 contains funds for the construction of a special oceanographic research 
ship. This will be the first oceanographic research ship specifically designed and constructed for oceanographic research by the United States Government. The last ship built and designed for this particular purpose in the United States was the Atlantis of the Woods Hole Oceanographic Institution, now over 29 years old. In addition to making funds available for the construction of a new ship, the Navy has recently converted three ships for oceanographic research: the 2000-ton Chain, now at the Woods Hole Oceanographic Institution, the 2700-ton Gibbs now at the Hudson Laboratory, and the 2000-ton Snatch, soon to be in service at the Scripps Institution of Oceanography. In addition to this substantial support of facilities in terms of ships, the Navy has increased its support of basic and applied oceanographic research by an appreciable amount.

Other Government agencies also have responded to the additional needs for oceanographic research. The National Science Foundation has obtained funds for an oceanographic research ship and in all agencies there has been an expansion in either the actual or planned support for oceanographic activities.

One of the peculiar problems of oceanography in the development of a nation-wide program is the number of agencies of the Federal Government having direct and indirect interests in such a program. Even before the Committee on Oceanography was organized, the need for coordination in planning various activities was recognized by personnel in these agencies. To meet this need an informal coordinating committee on oceanography has been holding monthly meetings in Washington for several years. Prior to the release of the Report of the Committee on Oceanography, the membership of this group consisted mainly of personnel from the Office of Naval Research, the U. S. Hydrographic Office, the Bureau of Commercial Fisheries, the Atomic Energy Commission, and the National Science Foundation. This group now consists of representatives from these agencies plus the Beach Erosion Board, Department of Health, Education, and Welfare, U. S. Coast Guard, U. S. Geological Survey, Bureau of Mines, Weather Bureau, State Department, Air Force, Maritime Administration, Bureau of Ordnance, Military Sea Transport Service, etc. These men function as a very effective working group in the coordination and planning of programs in each of these agencies. However, in order to embark upon a program of the magnitude visualized in the Report, some mechanism seemed necessary whereby the Executive Branch of the Government could make a policy decision on the need for such a program. With the completion of a special report prepared under the leadership of Dr. Killian, first Chairman of the President's Scientific Advisory Committee, a Federal Council on Science and Technology has been established. This Council consists of heads of each of the Government agencies which have scientific programs. One of the first acts of this Council was to appoint a Special Subcommittee on Oceanography, consisting of one individual each from the Department of Defense, the Department of Commerce, the Department of Interior, Atomic Energy Commission, and $\mathrm{Na}$ tional Science Foundation. Mr. Wakelin, Assistant Secretary of Defense for Research and Development, is Chairman of this Special Subcommittee. Under his leadership, the Subcommittee is conducting an intensive study of the Report of the Committee on Oceanography and the extent to which it meets the needs of the Government agencies. It is too early to tell yet what the results of the activities of this group will be. However, the enthusiasm and the seriousness with which they are studying the recommendations of the Committee on Oceanography is an indication of their concern over this problem. Thus we see a mechanism based on a large informal group at the working level in Government agencies working through a high level executive advisory committee to assist the executive branch in making administrative decisions regarding the need to support a particular branch of science. To some extent, this constitutes a new experiment in the design of a mechanism for development and administration of a program affecting many Federal agencies. Heretofore, a single agency has been assigned primary responsibility for budgeting and for carrying out a program. In the marine sciences, the responsibilities are so broad as to seem to preclude this solution, and instead to require some form of flexible joint planning and coordination.

Congress-Only a few days after the release of the Committee's Report in February, Congressman Herbert Bonner, Chairman of the 
House Committee on Merchant Marine and Fisheries, announced the formation of a Special Subcommittee on Oceanography. This Subcommittee, although contemplated earlier by $\mathrm{Mr}$. Bonner, was undoubtedly a direct response to the challenge presented in the Committee's Report for the development of a national marine sciences program. Mr. Bonner appointed Congressman George Miller of California as Chairman of this Special Subcommittee. Mr. Miller held a series of hearings during the spring and early summer of this year to establish background information on the existing oceanographic programs in the various Federal agencies and their plans for the future. Other members of the Subcommittee are: Willard S. Curtin (Pa.), John D. Dingell (Mich.), Francis E. Dorn (N. Y.), Gerald T. Flynn (Wisc.), Alton Lennon (N. C.), James Oliver (Maine), and Thomas M. Pelley (Wash.).

After hearing testimony from all the agencies primarily concerned with marine sciences, some members of $\mathrm{Mr}$. Miller's committee made a short visit to the Woods Hole Oceanographic Institution and attended part of a meeting of the Committee on Oceanography to obtain more insight into the philosophy and requirements of oceanography. Their activities during the next session should be of considerable interest to all oceanographers.

One other committee in the House, the House Committee on Science and Astronautics, has expressed a special interest in the Report. Congressman Brooks, Chairman of this Committee, introduced a bill early this year calling for special fellowships under NSF sponsorship for students in oceanography. Although the passage of this bill in its present form, or possibly even modified, seems doubtful, the hearing on the bill held during August of this year marked the first meeting of a new Subcommittee on Earth Sciences of the House Committee on Science and Astronautics. Mr. Brooks is chairman of this special Subcommittee and other members are: Perkins Bass (N. H.), J. Edgar Chenoweth (Colo.), Ken Hechler (W. Va.), Joseph E. Karth (Minn.), R. Walter Riehlman (N. Y.), and B. F. Sisk (Calif.). This group plans to consider the needs of all of the Earth sciences at future hearings.

In the Senate, the Committee's Report re- ceived almost immediate support from Senator Humphrey, who read the report into the Congressional Record, along with a strong statement of endorsement. In June, Senators Magnuson, Jackson, and Engle submitted a resolution to the Interstate and Foreign Commerce Committee calling the Committee on Oceanography's Report to the attention of the President and the Government agencies, and endorsing the need for effective action. Later this resolution with the sponsorship of the full Interstate and Foreign Commerce Committee was passed unanimously by the Senate.

One of the recommendations of the Report is that the Coast and Geodetic Survey join with the Navy in an ocean-wide, ocean-deep survey program. Since the charter of the Survey implies a restriction of the activities of that agency to the coastal waters of the United States, some legislation is required to permit effective operation by the Survey in deep oceanic waters. A bill to achieve this has been introduced and passed by the Senate. Similar legislation is under preparation by the House. However, the House did not act on the bill during the first session. Whether or not additional legislation is required to enable the Government agencies to expand their oceanographic activities remains to be seen. In general, the authority already exists for participation by any agency in that part of the program outlined by the Report. However, those smaller agencies which make up a fractional part of the interests and activities of larger departments of the Government doubtless will have an extremely difficult time in expanding their scope of participation except as a part of an overall coordinated program backed by the Executive and Legislative branches of the government. During the closing days of the 1959 Congressional session Senator Magnuson introduced a bill, S.2692, entitled Marine Sciences and Research Act of 1959. This bill, sponsored by 13 Senators, is now in the Interstate and Foreign Commerce Committee. Hearings are planned on the bill during the next session of Congress.

The inquiries and expressions of interest and support from Congress have been numerous. One thing seems certain: top-level Government administrators will have to be convinced not only of the necessity of the program outlined 
by the Committee but also of the fact that the program will be carried out as efficiently as possible, and with complete inter-agency cooperation.

Scientific response-The response of the scientific community has varied from complete endorsement to annoyance at the fact that a particular specialty of marine sciences has not been covered in the report and suspicion over the wisdom of placing particular attention on a special field of science. It is, of course, gratifying to have the approval of our scientific colleagues. The disapproving reactions seem to be based either on a lack of understanding of the objectives of the Report (that is the areas of interest covered and the motivations for preparing the report), or difference of opinion as to the mechanism for making Government policy regarding the support of science. After months of deliberation the Committee decided to emphasize those parts of oceanography which are of major concern to the well-rounded development of a national marine sciences program. For example, this meant emphasizing the construction of ocean-going research ships to replace existing obsolete vessels and build up our capability for research in the open oceans, while underemphasizing the need for ships for coastal research. It also meant stressing large programs of ocean surveying and construction of special large facilities for controlled environmental studies. Such large programs cannot be supported by a single institution, but require adequate backing on a national scale. Thus, many details of the type of research needed and capable of being carried out by smaller institutions in coastal waters of the United States were not specifically covered in the Report although the overall expansion necessary to develop a well rounded program would also include an increase in this type of activity.

Under its two charters, the first signed by Abraham Lincoln during the Civil War which established the National Academy of Sciences, and the second signed by President Wilson during the first World War establishing the National Research Council, the NAS - NRC has a direct responsibility to advise the Government on matters pertaining to science. The recent establishment of a Federal Council on Science and Technology is an additional indi- cation of the extent to which scientists must participate in formulating and advising the Government on matters of national importance. It seems there can be little doubt that the future development of our nation's capabilities in the marine sciences is a matter of concern not only to oceanographers and the Government, but also to the public.

Public response-A graph of the number of words contained in popular articles on oceanography would, we believe, show an abrupt increase starting in 1959. A large part of this interest probably was generated by the publication of the Report on Oceanography. However, equally important may be the growing realization among laymen that man is not soon to escape his troubles by joining an expedition to outer space. Few scientists are more excited by and interested in the prospects of exploring outer space than those that make up the membership of the Committee on Oceanography. Indeed, the Committee's Chairman is also a member of the Academy's Space Science Board. We certainly do not discount the importance of a vigorous program of space exploration and research. However, for the billions of persons who now inhabit the Earth, space can provide only an exciting diversion from the practical problems of survival and subsistence. The realization of this fact and the vast unknown and unexplored riches of the oceans undoubtedly accounts for the growing public interest in this forgotten frontier.

During 1959, two national news magazines, Newsweek and Time, ran feature stories on oceanography and the program of the Committee. At the writing of this report, a feature story is under preparation for Fortune Magazine on this subject. Articles have appeared in Sunday supplement magazines (as well as in the Sunday comic sections) and a high school student weekly news study guide. The daily press has been a frequent source of stories concerning the potentialities of the oceans. Surely no literate American will have gotten through 1959 without seeing the word "oceanography" at least once. Even the Reader's Digest published in a recent issue a condensation of the Time feature story, and Coronet magazine is expected to have a feature story before the end of the year. One popular report prepared 
by the Committee, and written by Dr. Athelstan Spilhaus, titled Turn to the Sea was released in August and has had to be reprinted because of the unexpectedly enthusiastic demand for copies.

This response and interest seems to be a positive sign that the legislators will receive support on the home front for any additional funds they may appropriate for the marine sciences.

\section{The Future}

The Committee hopes that its Report will stimulate an exhaustive appraisal by all of those involved in the marine sciences as to their own programs, the plans and ambitions of their agencies and institutions. Our future progress can be only as good and as well planned as the scientists in the marine laboratories ean make it and as ambitious as those in authority are willing to support. In its present form the Report is neither the perfect nor the last word in critical appraisal of the problems, potentialities, and methods for development of the marine sciences. Honest and objective criticism, personal thought and discussion, group discussions of objectives and methods are needed in great detail to realize the objective of an adequate development of this field which is so important to the security, well being and scientific development of our nation. 